the part affected, but I have since experienced no inclination to cultivate a close acquaintance with this apparently innocent, but really formidable caterpillar.

After the last larval moult, as most Lepidopterists are aware, the larva of Lagod opercularis presents an entirely different appearance from the one above described. The color is no longer white, but a dark gray, with fulvous or ochreous shadings on the dorsum and sides; the long hairs are replaced by a short and dense coating, resembling long-piled velvet, in which the stinging spines are more concealed than they were under the previous hairy coat. This larva is anomalous in one respect. It has, in addition to the four pairs of well-developed abdominal prolegs, two pairs of tubercles on joints 5 and 10 , which are not only used as locomotive organs, but are actually provided with the rudiments of hooks.

\title{
THE PREPARATORY STAGES OF LYCAENA COMYNTAS.
}

BY W. H. EDWARDS, COALBURGH, W. VA.

Last year I observed a female comyntas depositing eggs upon Desmodium Marilandicum Gray, a common and troublesome weed in this region, called "shoestring" by the country people, from its toughness of stem, and bearing a sticking burr in the fall. On 9th July, 1876 , I set a female in a bag over a stem of this plant, and several eggs were laid on the tender terminal leaves. Mr. Mead noticed that this butterfly laid also on red clover, and a number of eggs were obtained by the same process, on the I 3 th July, deposited on the young leaves and on the flowrets of the head. On the I 2 th, the eggs on Desmodium hatched; $5_{5}$ th, one larva passed ist moult ; I 8th, the 2 nd moult; 2 rst, the 3 rd moult ; on or about 26 th, the $4^{\text {th }}$ moult; made chrysalis 3 Ist, and the butterfly emerged August 9th. I raised but one of this brood to naturity, but ten on the clover. 'The single larva was green in all its stages, and its chrysalis was green, but the larve on clover were reddish or red throughout, and their chrysalids were sordid white. Whether this difference was owing to the food plants further experiment must determine. The larvæ at first were such minute 
objects as to be almost invisible, particularly on Desmodium, as both larva and plant were of nearly the same shade of green. On the clover they escaped sight down among the flowrets. Only by keeping them in small wine glasses could I have saved them. On clover, the tender leaves were rapidly eaten by the very young larva, a single larva eating out two or three furrows the width of its body, and side by side. As they became larger they seemed to feed on the calyces of the flowrets exclusively, curving themselves to the surface of the clover head, or burrowing into it. On Desmodium, as there were no flowers in bloon, only the tender leaves and immature flower buds were eaten. When about to change to chrysalis the larva rested motionless for several hours, usually on the upper surface of a leaf, the green shade becoming gradually yellowish, then red, rusty brown, and a loop was thrown over the body almost mid-length. When the change had occurred, the shape and appearance of the green chrysalis was so like that of the larva as to require some inspection to discover whether it was a chrysalis or no, lying flat on the leaf, the upper side rounded and of almost exactly the larval shape. To make the resemblance still closer, the chrysalis is as hairy as is the larva. I believe that wherever comyntas is found, two sizes of the butterfly appear, one of scarcely more than half the superficial area of the other. I do not know of any other species in which this peculiarity is regularly found. Both forms were among the butterflies from these chrysalids. The species is also dimorphic in the female, most of this sex here being black, the others blue with broad black margins. This phenomenon is similar to that of Pseudargiolus in its winter form violacea. At Coalburgh, there must be several successive broods of comyntas during the season, as fresh individuals are seen every month from April to September.

I subjoin a description of the several stages :

EGG; round, flattened, depressed at top, covered with a frost work of interlaced points; in color delicate green.

YOUNG LARVA; length . 05 inch; shape rather cylindrical; color yellowish, excepting a few white tuberculated points on dorsum, arranged in two longitudinal rows; a similar row at base of body ; from each of all these points arises a long, curved, white hair ; head nearly as broad as second segment, black, shining, retractile.

Following the larva which fed on Desmodium:

After FIRST MOULT; length .os inch; onisciform, flattened, the dorsum flat at top, sloping towards base of body; color greenish; the 
whole surface irregularly dotted with black; and from most, but not all, of the dots come white hairs, those on dorsum curved back, those nearer base curved partly downward and partly back; head obovate, long and narrow, smaller in proportion to and segment than at last stage, and partly concealed, even when active, in second segment; color black.

After SECOND MOULT; length . I 2 inch; broader and flatter than before; on each side of the narrow dorsal ridge a slightly raised edge, caused by the tubercles; at the base of the body a fold, and the hairs from this and the ridge are longer than elsewhere; whole surface finely pilose ; color green, but with a rusty tint caused by the numerous reddish points; above the fold these take the form of a line or slight stripe; at this stage the division of the segments becomes distinctly apparent.

After THIRD MOULT; length .20 inch; color clear apple green, the crests of the dorsal ridge, and also the fold at base, whitish; on either side of the white line thus caused at the fold, on several of the segments after the middle, but not on the two last, is a reddish line; there is also an indistinct double oblique line of pale green on side of each segment; head as at last stage.

After FOURTH MOULT; length .36 inch, greatest breadth .IO inch; onisciform, high anteriorly, the back rounded and sloping to last segment, which is much flattened; both ends (when the head is retracted) rounded equally, or nearly so ; each segment rounded dorsally; the whole upper surface covered with fine white hairs ; color emerald green with very many yellow tuberculous points; along middle of dorsum a deep green stripe in a depression; at base a whitish line edged with vinous on three or four segments after the middle; under side and legs pale green; head $.025 \mathrm{inch}$ in breadth, longer than broad, obovate, shining black, seen through the 2 nd segment when half protracted.

CHRYSALIS; length.26 inch; greatest breadth .10; shaped much like the mature larva, rounded at each end, tapering on the sides somewhat from segments 5 and 6 to head, roundly carinated dorsally, flattened on under side; the mesonotum but slightly prominent; color emerald green, except the abdomen both above and below, which is yellowish green; a dark green medio-dorsal stripe from end to end, and on either side of this a row of small round black spots, nearly the whole length; much covered with fine white hairs; on the top and sides of the anterior: segments the hairs are conspicuously longer, and are arranged in tufts, and similar hairs form a connected fringe quite round the abdomen. 
The larva which fed on clover differed in coloration as follows : color russet varying towards vinous, interspersed with green; at third moult some were pale green dorsally, the white being caused by the tubercles, the sides vinous; the dorsal stripe vinous, and the oblique lines vinous; others had the back as well as sides vinous, and this variation and character followed to maturity. The chrysalids of these larvae were sordid white on the whole upper surface and lower side of abdomen, the former specked with brown; the medio-dorsal stripe was brown, as were also the dots; under side of thorax and of head case, and the whole of the wing cases apple green.

\section{NOTES ON CERTAIN SPECIES OF MOTHS.}

BY A. R. GROTE,

Dixector of the Museum, Buffalo Society Natural Sciences.

\section{Phyprosopus callitrichoides Grote.}

Prof. Zeller published this species subsequently under the generic name of Sudariophora, which I, afterwards, adopted in lieu of my own. Prof. Zeller, however, now states that the generic character upon which he founded the name Sudariophora does not exist in reality. Accordingly, I now revert to the earlier name for the genus. The insect was erroneously identified as Doryodes acutaria by Mr. Walker, and referred by him to the Pyralidæ in the British Museum lists, where it is recorded as Doryodes acutalis. It does not seem to have been separately named before I described it. Dr. Packard discusses the position of the species in his work on the Geometre, p. 33, and finds that "the palpi are truly noctuiform, as well as the shape of the wings." In criticising Prof. Zeller's classification of the moth, Dr. Packard omits to state that I had described it previously under the Noctuidæ. Consult Zeller, Beitr., 328-9.

\section{Caterva catenaria (Drury).}

The new generic name is proposed since our species is generically distinct from the European forms referred to Zerene Treits., a genus which, 